\title{
PROPOSAL FOR A LABOR-MANAGEMENT BOARD AND A CHARTER OF FAIR LABOR PRACTICES*
}

\author{
LIOYd K. Garrison $†$
}

I

$7 \mathrm{HE}$ proposal outlined in this article relates only to the development of policies and procedures for the avoidance and settlement of major industrial conflicts. It is not advanced either as a substitute for, or as a supplement to, legislation designed to deal with real or imagined union abuses. It is intended to stand on its own feet. I venture to prophesy that any legislation which Congress is likely to enact in this session, of the sort heretofore introduced, will not help to avoid the serious strikes which are the chief object of public concern. Indeed, as I shall indicate a little later, some of the pending proposals, if they were to become law, would be likely to increase rather than to allay unrest. I shall not attempt, however, either to analyze the pending legislation or to discuss what might appropriately be done to check certain improper practices which some unions have engaged in, because I do not wish to divert attention from what seems to me to be the heart of the problem.

I would state that problem as follows: What can be done to avoid major industrial conflicts in which there are involved no elements of wrongdoing

\footnotetext{
* This article contains the substance of a memorandum which I prepared in Jannary, I947, and circulated among a small group of industrialists and labor leaders with whom I was personally acquainted. The responses were favorable, but the industrialists were in general preoccupied with the enactment of legislation aimed against particular practices on the part of some unions and aimed also at the size and power of unions; and they expressed doubts as to the willingness of the leaders of industry and labor to give the necessary time to the work of a joint board such as this proposal envisages. Subsequently the Research and Policy Committee of the Committee for Economic Development issued on February 24, 1947, a public statement on "Collective Bargaining: How To Make It More Effective," and in this statement the Committee recommended, among other things, the establishment of a labor-management council substantially along the lines of the proposal herein discussed but with some differences worth noting, to which I shall draw attention. The point is that the Research and Policy Committee of the C.E.D., consisting of twenty-one leading industrialists, including such men as Paul G. Hoffman (chairman of the C.E.D.), Beardsley Ruml, Eric Johnston, Jay C. Hormel, Fowler McCormick, Philip D. Reed, and others, have gone on record in favor of the establishment by the government of a joint board of leaders of industry and labor to promote industrial peace by joint agreement from time to time upon policies and procedures. I submit that if Congress were to establish such an agency, top-notch men could be found to serve upon it.

$\dagger$ Member of the firm of Paul, Weiss, Wharton and Garrison, New York; formerly Dean of University of Wisconsin Law School, and General Counsel and later Executive Director and Vice-Chairman of the National War Labor Board.
} 
but only the question of what the terms of employment should be? I shall assume that any legislation which is likely to be enacted will not materially affect either the power or the philosophy of the labor and industrial groups which now confront each other in the basic industries, and that therefore the problem, as I have posed it, will continue to be with us for a long time to come. Indeed, it seems to me to be inherent in the environment. You cannot today have big industry without big unions, and wherever you have the combination of the two you will run the risk of large and protracted strikes over the terms of employment; and no amount of legislation dealing with such matters as secondary boycotts, jurisdictional disputes, breaches of contract, closed shop, and the like, will bring us any closer to a solution of the difficulty.

In the search for a solution I believe that we must place primary reliance upon the capacity of industry and labor to hammer out, by agreement, policies and procedures which will keep the conflicts over terms of employment within reasonable bounds. I do not believe that legislation can accomplish this. We can only make progress the hard way-by agreement. That does not mean, however, that the government should just sit back, do nothing and hope for the best. On the contrary, government can and should exercise initiative and leadership in bringing the leaders of industry and labor together in a functional relationship designed to bring about a maximum degree of agreement.

The proposal herein outlined is directed to that end. I should like to state a little more fully the premises on which it rests. They are:

(I) The major issue in the large-scale industrial disputes of today is the wage issue. At the time of Pearl Harbor, the question of the closed or union shop versus the open shop was very much to the fore and was greatly troubling the country, but it was put to rest during the war by the maintenance of membership compromise evolved by the National War Labor Board. ${ }^{x}$ Since the war, employers and unions have for the most part been able to work out compromises of their own through collective bargaining in cases where the union shop or the closed shop has been refused by the employers. These compromises have generally involved either some form

\footnotetext{
I Under the War Labor Board's standard form of maintenance of membership, the union members in a plant had fifteen days in which to withdraw voluntarily from the union if they did not wish to be bound to remain members during the balance of the contract period. Those who did not withdraw during the fifteen days were bound to remain in the union as a condition of employment. Non-union employees were not required to join the union. The employer was free to hire whomever he wished. Employees who voluntarily joined the union after the lapse of the fifteen-day period were required to remain in the union for the balance of the contract period. Often some form of check-off (voluntary and revocable, or voluntary and irrevocable, or mandatory for all union members) was directed in addition to maintenance of membership.
} 
of maintenance of membership or some form of check-off ${ }^{2}$ or both. Not one of the important post-war strikes has been fought over questions of union security. They have been primarily concerned with wages: first in relation to the cutback of hours to the normal peacetime work week, which resulted in a substantial reduction in weekly earnings; ${ }^{3}$ and subsequently in relation to the cost of living. If we could make progress in evolving formulae and standards for the determination of wage levels in different industries and in different areas, the greatest single cause of industrial conflicts would be obviated. These formulae and standards can, I believe, only be evolved by agreement.

(2) While controversies over wages are the most prolific source of industrial conflict today and while ways of settling these controversies without costly stoppages must continue to be the primary objective of national policy, attention must be given to other important questions which frequently result in strife. The union security issue is still troublesome in many plants. The determination of the line between those functions which should be exclusively managerial and those in which the union should participate gives rise to many sharp controversies and needs intensive study. As workers grope for security, questions of guaranteed annual

2 Including in some instances check-ofis of an amount equivalent to the union dues, applicable to all employees, whether union members or not. This type of agreement, which has received its most prominent form in the so-called Rand Plan in Canada, worked out by Judge Rand in the settlement of the Ford strike at Windsor, proceeds on the theory that since all employees benefit from the collective agreement negotiated by the union and from the grievance machinery maintained jointly by the union and the employer, they ought to pay their share of the upkeep of the union during the life of the contract. The same theory, of course, is advanced as an argument in favor of the closed shop or the union shop agreement, but these agreements, in addition to making every worker pay dues, require them to keep up their membership in the union in good standing, and thus give the union a strong disciplinary control over the members. This control may be exercised to discourage dual unionism in the plant, and in that respect its exercise promotes industrial peace and is to the interests of the employer as well as the union. On the other hand, the power of discipline may be abused as a result of union politics or personal antagonisms, and many employers object strongly to discharging men for reasons other than the non-payment of dues. The check-off, whether applied to union members only or to all employees, relieves the employer from ever having to discharge anyone. At the same time it does tend to weaken the authority of the union, which may be needed not only to discourage organizing campaigns by outside unions but to help police the agreement by disciplining persons responsible for wildcat stoppages and other breaches of contract. It should be noted, in addition, that some unions oppose the check-off because it does away with the monthly contact between the union officials and the members, particularly where, as is often the case, the members are supposed to go to union headquarters to pay their dues. There are other unions, however, which strongly favor the check-off because by relieving the stewards and committeemen from having to collect dues, they can devote more time to the handling of grievances.

3 The strikes in the automotive, steel, and other basic industries in the winter and spring of 1946 primarily resulted in compromising the loss in weekly take-home pay at figures which resulted in the absorption by the companies of anywhere from one-half to three-fourths of the loss, through increases in hourly rates. 
wages, severance pay, pension plans, and the like are beginning to come to the fore. In-plant relationships and procedures for the settlement of grievances and the promotion of worker morale are assuming a new importance as we learn more about the psychological factors which produce unrest. In all these fields there is urgent need of labor-industry co-operation at the highest levels of national leadership as well as all along the line.

(3) Governmental determination of wages and other terms of employment in major industries, whether brought about through boards or courts, and whether through legal compulsion or public pressure, will undermine collective bargaining and may in the end result in governmental controls over prices and production.

It would be difficult to conduct a limited experiment with governmental intervention of this sort. Proposals have been made for establishing compulsory arbitration only in industries particularly charged with a public interest, such as electric power production; but it would be hard to do this without extending the process throughout the basic industries such as coal, steel, railroads, shipping, communications, oil, and others, the stoppage of any one of which would sooner or later vitally affect the country. Compulsory arbitration upon any such scale would introduce a dangerous degree of governmental interference with the flexibility of the wage-price structure, which is the present basis of our whole economy. Moreover, as a long experience in Australia and experiments in Great Britain in the first World War have abundantly demonstrated, compulsory arbitration often fails to work because, in a democracy, masses of men simply cannot be prevented from striking when they believe that a particular governmental decision is unfair or unjust.

The plain fact of the matter is that so long as we have a democracy and a system of relatively free enterprise, we are bound to have a certain amount of industrial strife which will be greater in some periods and less in others; and it would seem to be the better part of wisdom to look to collective bargaining, imperfect as its results may be, to settle the differences that arise than to embrace another imperfect method of settlement, namely, compulsory arbitration, which carries with it much evil of its own. No doubt we may be faced occasionally with strikes of such a magnitude and duration as to threaten the welfare of the whole community, but it would seem better to meet an occasional crisis of this sort by improvised methods of settlement, as we have managed to do in the past, than to hold out in advance to the contestants an assured procedure for getting the government to write a contract for them. After all, we have weathered each crisis thus far by one means or another adapted to the par- 
ticular emergency, without embarking upon formidable adventures in the way of governmental dictation of the terms of employment, and I see no reason to suppose that we cannot continue to get along in this way in the future.

We must always remember that, after all, industrial workers are a part of the public; they are average Americans who are profoundly influenced by what their community wants and thinks. In this fact lies our ultimate safety. And we must remember also that throughout most of industry our labor relations have scarcely emerged from the formative stage and that the curve of development for a long time to come will be in the direction of greater maturity and responsibility, with wisdom building upon experience. The time is therefore ripe for a forward effort on the part of the leaders of industry and labor to develop policies and procedures which will make collective bargaining work more effectively.

(4) The objective of national policy should therefore be to buttress and support the processes of free collective bargaining. The best and perhaps the only way in which fundamental progress can be made in this direction is by encouraging common agreement and joint efforts on the part of the representatives of industry and labor nationally, and in local communities, and in particular industries. Toward this end the government should give all the aid it can, short of interfering in the final determination of policies and decisions.

(5) Progress in the formulation of overall policies by agreement was made through national management-labor conferences called by the President at the start of World Wars I and II, and in November, x945. However, the fruits of this progress have been insufficiently capitalized upon. In particular the unanimous agreements reached by the conference of November, I945, deserve to be proclaimed as national policy, and to be added to thereafter by joint effort.

(6) The experience of the National War Labor Boards in World Wars I and II, in reaching unanimous agreement upon many important questions of basic policy, demonstrated the utility of a continuing, organized relationship between representatives of industry and labor. A similar continuing, organized relationship may prove beneficial in peacetime and may hold out more promise of progress by agreement than reliance exclusively upon occasional ad hoc management-labor conferences.

The proposal outlined herein is designed to establish a relationship of that sort. Before taking it up, I should like to discuss briefly a portion of the pending Taft-Ball-Smith Bill ${ }^{4}$ which deals with the problem of settling and avoiding major strikes. I select this measure for comment only be-

4S. 55, 8oth Cong. Ist Sess. (1947). 
cause it seems to me to be typical of many attempts to set up governmental machinery for the avoidance of strikes, involving some elements of compulsion, which I fear will have effects in practice quite contrary to those intended by the draftsmen.

Title I of this bill creates a five-man all-public mediation board "in the Department of Labor." The existing Conciliation Service is put under it. ${ }^{5}$ Section 3 (b) provides in effect that whenever the board proffers its services in any labor dispute there shall be no strike or lockout for sixty days (unless prior thereto the board certifies that its efforts at mediation are concluded - a confession of failure which one may expect would not often be made). This plausible provision is likely to have these unforeseen consequences:

(a) It would be to the interest of every union entering upon negotiations to get the board to proffer its services at the earliest possible moment. For if the union and the company negotiated for two or three months without reaching a settlement, the board could intervene on the eve of a strike and prolong the period for another two months. In order to avoid such a stretching out of the negotiations, the union would be likely at the very outset to try to get the board into the picture so that the sixty-day period would begin to run, after which the union would have a free hand. The way to do this would be to make exorbitant demands and noisy threats, so as to give the appearance of an imminent crisis.

(b) These tactics would then gravely disturb the collective-bargaining atmosphere. They would stiffen the employer's resistance and make it harder for the union to recede from its extreme demands.

(c) Once the board had proffered its services, it would tend to develop into a fact-finding, recommendatory agency, making public reports on the merits of unsettled controversies and putting the government to that extent into the business of determining wages and other conditions of employment. ${ }^{6}$ Certainly there would be a good deal of public pressure on the board to state its position in controversies which were upsetting to the

s Being "in the Department of Labor" means, among other things, that the board's budget would be controlled by the Secretary of Labor. The proposal really amounts to no more than adding five good Presidential appointees to the Conciliation Service to head it up. This is a net gain, but not much, because under the set-up it would be difficult to get really first-rate men to serve. The apparent independence of the board would not be real because of the Secretary's budgetary control, and conflicts, jealousy, and friction would be likely to arise between the Secretary, whose prestige would be diminished by the bill, and the five Presidential appointees who would be injected into his establishment.

${ }^{6} \mathrm{I}$ do not wish to suggest that the appointment of fact-finding boards would not sometimes be useful. If carefully selected on an ad hoc basis, and used sparingly, and only where there was good reason to expect that they might succeed as a sort of dressed-up mediation board or as a face-saving instrument, they could continue to do good work, as they have done in the past. 
public, and the board would be tempted to take this course whenever it had failed to effect a settlement. And those unions which think they can gain most by getting governmental agencies to recommend terms beyond what the employer would offer would do their utmost to get the board to make reports of this sort.

(d) Because of the risk that labor disputes would terminate in this sort of semi-adjudication by the board, employers might become chary of making any proposals to the union in negotiations which could be used as a floor above which the board would build. Thus collective bargaining would be undermined.

None of these results might actually occur. But our experience to date with governmental cooling-off periods and other forms of governmental intervention indicates that there would be enough danger in this type of proposal to warrant the adoption of an alternative policy designed to bring about the maximum degree of co-operation between the leaders of industry and labor in the development of policies and procedures for settling and avoiding major conflicts.

II

The outline of an Act of Congress which now follows is suggested as one way of translating that policy into practice. I have not attempted to put this outline into formal statutory language, but only to indicate what its salient features might be.

\section{OUTLINE OF AN ACT OF CONGRESS}

\section{Purposes of the Act}

The purposes of this Act are to facilitate the avoidance and settlement of industrial disputes by collective agreements between unions and employers without strikes or lockouts, and to provide means for assisting and encouraging representatives of labor and management to develop through joint efforts policies and procedures designed to make collective bargaining function effectively in the public interest.

\section{Establishment of a National Labor-Management Board}

A. A National Labor-Management Board is hereby created as an independent agency of the government, to be composed of the following:

(I) Five representatives of labor, each with an alternate, to be appointed by the President after consultation with the major organizations of labor;

(2) Five representatives of industry, each with an alternate, to be ap- 
pointed by the President after consultation with the major organizations of industry;

(3) A chairman, to be jointly nominated by the foregoing members and appointed by the President;

(4) The Secretaries of Labor and Commerce, ex officio;

(5) The chairmen of the Senate and House Committees on Labor, ex officio. ${ }^{7}$

$B$. Any action of the board may be taken by, and no action may be taken without, the affirmative vote of four of the five labor members and four of the five industry members.

$C$. The labor and industry members, and the chairman, will be appointed for one year terms, and may be eligible for reappointment. They will serve on a per diem basis, with a full-time executive secretary.

$D$. The board may call upon the secretaries of Labor and Commerce from time to time for special staff assistance, research and investigations, and may appoint such additional personnel as is needed to enable the board to carry out its duties.

$E$. The duties of the board shall be as follows:

(I) To consider ways and means of developing and supporting voluntary procedures for the avoidance and settlement of strikes, in general, and also in particular industries, areas and communities, as the needs may indicate;

(2) To study the causes of industrial peace as well as industrial unrest, and to bring to the attention of industry, labor and the public, any lessons learned through such study, including in the study an analysis of local or industry-wide experiments and procedures for the avoidance and settlement of disputes, with a view to encouraging the wider adoption of methods which have proved successful in practice;

(3) To promote more effective methods for arbitrating jurisdictional disputes;

7 The C.E.D. proposal is for a Labor-Management Council within the Department of Labor "for housekeeping purposes" but independent as to its operations and policies. Its members (unspecified as to number) would be appointed by the President "upon the joint recommendation of the Secretaries of Commerce and Labor with the advice and consent of the Senate" (a pretty neat suggestion). The two Secretaries and the Chairmen of the Senate and House Committees on Labor would not, as in my draft, be ex officio members, but the Council would be required to meet with them "at regular intervals. . . . so that there may be a continuing and direct contact between the executive and legislative branches of government and the representatives of labor and management on matters affecting industrial peace." The C.E.D. proposal contains no provision for a chairman, which seems to me to be a lack, since there ought to be some one on the board charged with responsibility for seeing to it that the board met regularly and that its business moved along. 
(4) To study the experience with labor-management production committees during the war, and other experiments in co-operation for the improvement of efficiency and productivity, and to encourage the taking of appropriate further steps in these directions;

(5) To appoint arbitrators or emergency boards or investigators at the joint request of the parties to particular disputes certified to the board by the Secretary of Labor as vitally affecting the national welfare;

(6) In disputes so certified, to recommend to the parties or to the President, on the board's own motion, particular courses of action or procedures for settlement, not involving the board in the merits of the dispute or in findings of fact, whenever in the board's judgment such recommendations can usefully be made and need to be made in the public interest; ${ }^{8}$

(7) In aid of its duties, to hold hearings or conferences, conduct investigations and issue publications;

(8) To recommend any legislation which in the board's judgment may be needed for the proper functioning or strengthening of the board or for the support of voluntarily developed procedures for the settlement of disputes; to report its activities annually to Congress; and to submit its views to Congress or the President upon particular questions when requested so to do;

(9) To encourage adherence by unions and employers to the principles unanimously adopted by the President's National Labor-Management Conference of November, I945, regarding the making of initial collective agreements, and the administration and maintenance of collective agree-

${ }^{8}$ The major differences between the C.E.D. proposal and the foregoing, with regard to functions, are as follows: (a) the C.E.D. proposal omits item (4) having to do with the promotion of efficiency and productivity-a note I should like to see included; (b) the C.E.D. proposal omits item (5) relating to the appointment of arbitrators, etc., at the joint request of the parties, and item (6) relating to procedural recommendations for the settlement of a limited group of critical controversies. The C.E.D. would have the council stay out of disputes altogether. At present, as a result of the action taken in November, I945, by the President's National Labor-Management Conference, there is attached to the U.S. Conciliation Service a joint labor-management advisory board which passes on appointments of arbitrators and mediators. The C.E.D. would in effect lift the level of the Director of the Conciliation Service and of this advisory board by having both appointed by the President and confirmed by the Senate, and would then broaden the duties of the joint board by having it make studies and meet with the Secretaries of Labor and Commerce and the House and Senate Labor Committee chairmen, as already described, and make an annual report to the President with recommendations for improving industrial relations. The joint board, or council, as the C.E.D. would call it, would continue to pass on appointments of arbitrators and mediators, but it would not appoint them itself, nor would it undertake any direct functions, however limited, in labor disputes. My own preference would be to leave the Conciliation Service intact with its present joint advisory board, and then create an independent labor-management board of a higher order, with limited functions in disputes as suggested in my items (5) and (6). If leaders of industry and labor would be willing to perform these functions, I think that the country would be the gainer. The C.E.D. coolness toward this suggestion may indicate that industry, at least, is not ready to take on such responsibilities; perhaps labor is not either. 
ments (said principles being set forth hereinafter in Part III of this Act for the guidance of industry and labor and the information of the country);?

(Io) To formulate (or propose or call labor-management conferences to formulate) further statements of the principles and policies which should govern management and labor in their collective relations, and to promulgate, distribute and encourage adherence to, the principles and policies so formulated, considering particularly, as areas in which to seek the maximum degree of joint agreement, wage policies, measures for stabilizing employment, and the delineation of the functions of management and labor. ${ }^{x 0}$

\section{A Charter of Fair Labor Practices}

The principles hereinafter set forth in this Part III, having been unanimously agreed to by the President's National Labor-Management Conference of November, I945, are hereby designated as a "Charter of Fair Labor Practices" and are declared to constitute national policy. They are published for the information of the country and as a guide to representatives of industry and labor in collective-bargaining negotiations and in the administration and maintenance of collective agreements. As further principles are elaborated by agreement, pursuant to paragraph to of Section $\mathbf{E}$ of Part II of this act, the board hereinabove provided for may publish them as an integral part of this Charter of Fair Labor Practices, so that the charter shall constitute a developing document embodying at any

9 The C.E.D. proposal contains nothing comparable to items ( 9 ) and (Io) above. It seems to me that a real step forward would be taken if Congress were to embody in statutory form, as a sort of charter of fair labor practices-unenforcible in the courts but carrying weight nevertheless as a declaration of public policy-the principles already agreed to by the LaborManagement Conference; and further, if Congress were to call upon labor and industry, through the medium of the joint board, to keep on developing and adding to this charter, as in item (Io).

so These three areas-wage policies, measures for stablizing employment, and the delineation of the functions of labor and management - are the hardest and the most important for industry and labor to explore together. At the 1945 conference the first two were not considered at all, and on the third no agreement could be reached (see pp. 43 to 73 of Vol. III of the Proceedings for an interesting clash of views which may be, however, less irreconcilable than then appeared). The industry group, joined by the AFL representatives, opposed the request of the CIO representatives to discuss wage policy. In the light of the strikes which thereafter followed, it seems regrettable that not even an attempt was made to lay down standards and guides for easing the country through the major wage adjustments which were then inevitable. However, price controls were still in force and the government may perhaps be criticized for not having called upon labor and industry to meet with its own representatives to formulate a workable wage-price policy for the transition to peace-time production. In any event, the formulation by agreement of yardsticks and standards for wage-fixing should henceforth be at the forefront of the efforts of labor and industry. This is why I would mention it specifically in the actas a matter of emphasis-along with the other major policy questions specified above. The C.E.D. proposal contains no comparable provisions. 
given time the best views of the leaders of industry and labor regarding their mutual relationships. The initial charter shall read as follows: ${ }^{1 x}$

$A$. The Making of Initial Collective Agreements ${ }^{12}$

(x) Collective bargaining undertaken promptly and in good faith, following recognition of a properly established bargaining agent either by acceptance by the employer or by operation of lawfully constituted procedures, is viewed as the first step to avoid strike action by the union or refusal to bargain by the employer.

Observance of the following widely applicable rules will contribute to orderly and peaceful procedures in making the first contract:

(a) The employer should not question his obligation to bargain with the union chosen as the bargaining agent for all employees in a properly established bargaining unit.

(b) Neither side should delay immediate establishment of bargaining relationships and commencement of contract negotiations.

(c) In their negotiations, the parties should look toward the preparation of a signed agreement covering a defined period of time.

(d) Before specific bargaining on individual items is undertaken, each party should present to the other a general statement of its position and the parties should then explore them jointly. Areas of agreement should be carefully sought. Precise definition of the issues also should precede specific bargaining. In consummating their first agreement, the parties should carefully define its scope and terms.

(e) It is well that respect and consideration be given to proposals presented by either the employer or the union and every reasonable effort made to bring about accord before any unreasonable ultimatum is issued by either side. Both sides should avoid inflammatory statements which question the sincerity or good faith of the other party.

(f) Both parties should avoid threats or actions which interfere with normal operations while negotiations are still proceeding in good faith and until all other peaceful procedures have been exhausted. ${ }^{13}$

(2) Conciliation should be employed by the parties if collective bargaining has not resulted in agreement. Such conciliation may be private or public, and if public, local, state or federal, as best suited to the circumstances.

Conciliation, however, should not be the first resort of parties, but should be undertaken only after reasonable time and full effort to reach agreement has been made by direct negotiation.

${ }^{2 x}$ What follows has been taken verbatim, from pp. I29-3I, I4I-43, and 32 , of Volume III of the Proceedings of the Conference.

${ }^{12}$ This is the first formulation of principles in the labor field ever agreed to by leading representatives of industry and labor. The reasonable and common sense nature of these principles should not obscure the great advance marked by their formulation. Before the war no such agreement could conceivably have been reached.

$x_{3}$ These six principles, if given support by Congress, should be of considerable assistance to mediators, as well as to the parties themselves. 
The conciliator should, wherever possible, be invited by both parties to participate. If that is not possible, the best practice is for the party inviting the conciliator to notify the other party of this action.

(3) If direct negotiations and conciliation have not been successful, voluntary arbitration may be considered by the parties; however, before voluntary arbitration is agreed upon as a means of settling unsettled issues, the parties themselves should agree on the precise issues, the terms of submission, and the principles or factors by which the arbitrator shall be governed. ${ }^{14}$

\section{$B$. The Administration of Collective Agreements}

(I) Collective-bargaining agreements should contain provisions that grievances and disputes involving the interpretation or application of the terms of the agreement are to be settled without resort to strikes, lockouts or other interruptions to normal operations by an effective grievance procedure with arbitration as its final step..$^{x}$

${ }^{14}$ The limited use of arbitration for the settlement of contract terms (as distinguished from the interpretation of contract terms already agreed to, which is discussed in the section immediately following) is due just to this difficulty, namely, of agreeing upon the "principles or factors by which the arbitrator shall be governed." Employers and unions hesitate to commit to an "outsider" the fixing of contract terms where his frame of reference is very broad. (All the more so are they opposed to compulsory references in such circumstances.) When the arbitra-

- tor is given rules or standards by adherence to which he cannot go very far wrong, one way or the other, the parties are much more apt to be willing to entrust their fates to him. One of the most successful arbitrators in the country, who for years has set the annual wage-scales in a particular industry, once told me that the parties were willing to let him do this only because he made it a practice to explore the true necessities of each side in a series of separate, private, off-the-record conferences, and because he would not proceed to a judgment until he was satisfied that he understood about where the breaking-point of each side lay, so that if he hit somewhere in between the result would be bearable. A procedure of this sort, however, could be successful only under exceptional conditions; it would call for an unusual degree of personal confidence in the arbitrator and of shrewdness, tact, and wide knowledge of the industry on his part. In most cases these conditions are not all present, and since they are not, it becomes particularly important in the wage field (which is the most difficult to arbitrate) for industry and labor to formulate by agreement yardsticks and limiting principles for the guidance of arbitrators. Not nearly enough effort has been put into this undertaking, and its importance cannot be exaggerated.

${ }^{15}$ This agreement upon arbitration as the final step in grievance procedures marks one of the great war-time gains in labor relations. Before the war the practice was very limited and was strongly resisted. During the war the vital necessity of maintaining uninterrupted production led to a new interest in procedures for settling grievances and day-to-day disputes within plants. On February 28, I944, the industry, labor and public members of the National War Labor Board unanimously adopted a resolution calling upon employers and unions "to install adequate procedures for the prompt, just, and final settlement of the day-to-day grievances involving the interpretation and application of the contract"; "to make the full functioning of the grievance procedure a major responsibility under the no-strike no-lockout agreement for maximum production to win the war"; and, "even in the absence of established grievance procedures, to settle grievances through direct negotiation and, if necessary, voluntary arbitration." Subsequent pronouncements and actions of the board developed further the concept and practice of arbitration under grievance procedures, so that by the time the war had ended a really significant change had occurred in the thinking of both industry and unions with regard 
(2) To be effective, the procedure established for the settlement of such grievances and disputes should meet at least the following standards:

(a) The succéssive steps in the procedure, the method of presenting grievances or disputes, and the method of taking an appeal from one step to another should be so clearly stated in the agreement as to be readily understood by all employees, union officials, and management representatives.

(b) The procedure should be adaptable to the handling of the various types of grievances and disputes which come under the terms of the agreement.

(c) The procedure should be designed to facilitate the settlement of grievances and disputes as soon as possible after they arise. To this end:

I. The agreement should provide adequate stated time limits for the presentation of grievances and disputes, the rendering of decisions and the taking of appeals;

2. Issues should be clearly formulated at the earliest possible moment. In all cases which cannot be settled in the first informal discussions, the positions of both sides should be reduced to writing;

3. Management and union should encourage their representatives to settle at the lower steps grievances which do not involve broad questions of policy or of contract interpretation and should delegate sufficient authority to them to accomplish this end;

4. The agreement should provide adequate opportunity for both parties to investigate grievances under discussion;

5. Provision should be made for priority handling of grievances involving discharge, suspension, or other disciplinary action.

(d) The procedure should be open to the submission of grievances by all parties to the agreement.

(3) Management and unions should inform and train their representatives in the proper functioning of the grievance procedure and in their responsibilities under it. In such a program it should be emphasized:

(a) That the basic objective of the grievance procedure is the achievement of sound and fair settlements and not the "winning" of cases.

(b) That the filing of grievances should be considered by foremen or supervisors as aids in discovering and removing causes of discontent in their departments.

(c) That any tendency by either party to support the earlier decisions of its representatives when such decisions are wrong should be discouraged.

to the settlement of grievances through arbitration. This method now came to be looked upon by many influential employers and unions as normal and indeed indispensable. It remained for the 1945 conference to give to these views a formal and impressive backing. It is important to note the essential difference between arbitration under an existing contract and arbitration of the terms to be embodied in a new contract. In the former case the arbitrator is merely interpreting and applying the parties' own language; in the latter case he is making a contract for them. In the former case bis scope is narrowly confined, so that even if he makes mistakes he cannot go very far afield; in the latter case, in the absence of agreed-upon yardsticks and limitations, his discretion is unfettered and he may do real damage to one side or the other through ignorance or misunderstanding. For these reasons arbitration of new contract terms has made relatively little headway, while arbitration of grievances under existing contracts is rapidly becoming universal. 
(d) That the willingness of management and union officials to give adequate time and attention to the handling and disposition of grievances and disputes is necessary to the effective functioning of the procedure.

(e) That for the sound handling of grievances and disputes both management and union representatives should be thoroughly familiar with the entire collective bargaining agreement.

(4) The parties should provide by mutual agreement for the final determination of any unsettled grievances or disputes involving the interpretation or application of the agreement by an impartial chairman, umpire, arbitrator, or board. In this connection the agreement should provide:

(a) A definite and mutually agreed upon procedure of selecting the impartial chairman, umpire, arbitrator, or board.

(b) That the impartial chairman, umpire, arbitrator, or board should have no power to add to, subtract from, change, or modify any provision of the agreement but should be authorized only to interpret the existing provisions of the agreement and apply them to the specific facts of the grievance or dispute.

(c) That reference of a grievance or dispute to an impartial chairman, umpire, arbitrator, or board should be reserved as the final step in the procedure and should not be resorted to unless the settlement procedures of the earlier steps have been exhausted.

(d) That the decision of the impartial chairman, umpire, arbitrator, or board should be accepted by both parties as final and binding.

(e) That the cost of such impartial chairman, umpire, arbitrator, or board should be shared equally by both parties.

(5) Any question not involving the application or interpretation of the agreement as then existing but which may properly be raised pursuant to agreement provisions should be subject to negotiation, conciliation, or such other means of settlement as the parties may provide.

(6) Where an agreement contains a renewal clause and a change or modification or reopening of the agreement is requested by either party or where the existing agreement is about to be terminated, ample time prior to the termination of the agreement should be provided for the negotiation of a new or modified agreement. If such negotiations should fail, the parties should make early use of conciliation, mediation, and, where mutually agreed to, arbitration.

C. The Maintenance of Collective Agreements ${ }^{16}$

(I) The customary provisions incorporated in collective-bargaining agreements which permit management to discipline any employees subject to their right to appeal through the grievance machinery of the agree-

${ }^{26}$ This section, in a few crisp sentences, codifies two more highly significant gains in labormanagement thinking: ( $\mathrm{I}$ ) the importance and necessity of management's right to discipline, and the correlative right of the disciplined employee to appeal his penalty through the griev- 
ment for any violation of its provisions are desirable and necessary for the proper administration of the agreement.

(2) Management and unions must require that their respective officials refrain from encouraging or engaging in contract violation. The parties must establish and enforce such regulations as may be necessary within their respective jurisdictions to insure absolute unqualified adherence to the contract commitment made.

\section{III}

I have presented the foregoing draft of an Act of Congress not because I thought its details important, but because it embodies, and therefore may help some people to visualize more clearly, what I believe to be the basic principles of a sound labor program, namely:

(I) That, in a democracy such as ours, fundamental progress toward the avoidance and peaceful settlement of industrial conflicts can only be made by agreement between industry and labor upon policies and procedures designed to buttress collective bargaining and to make it work more effectively and without serious breakdowns;

(2) That the establishment of a continuing, organized relationship between the leaders of industry and labor holds out the best hope of furthering agreement along these lines;

(3) That as a practical matter the establishment of such a relationship can only be effected by the government, and that the government should lend every aid to bringing it about and maintaining it, while continuing to mediate in the field; and

(4) That the government should, in addition, capitalize upon the significant agreements heretofore reached by the leaders of industry and labor, by publishing them in statutory form, not as compulsory edicts but as a charter of fair labor practices constituting national policy; after which the leaders of industry and labor should be charged with responsibility, in their continuing, organized relationships, for further developing and adding to this charter.

I do not hold out these four principles as panaceas. I do not believe that in a free-market economy such as we are trying to maintain we can altogether avoid situations in which workers, emulating the price policies of other producers, will withhold their services in order to raise or maintain

ance procedure after the discipline has been imposed (any remissions of penalties being made retroactive); (2) the importance and necessity of adhering to contracts, and the positive obligation resting on both parties to co-operate to that end. These convictions, which had begun to take shape before the war, were greatly strengthened by the war-time need of maximum production. 
the price of their labor. The best we can hope for is to minimize the interruptions by agreement.

And I think it important to add, in conclusion, that labor relations do not exist in a vacuum. They are deeply affected by what happens to the country generally, just as the country's welfare is deeply affected by what happens to the world at large. If we can so manage our affairs, at home and abroad, as to give people hope, and a sense of security, and an opportunity to develop their talents and to build a decent life for themselves and their children, the collective-bargaining process will work well; but if we fail in these endeavors, the collective-bargaining process, like the peace of mankind, can only deteriorate. 